\title{
IAMJ
}

INTERNATIONAL

AYURVEDIC

MEDICAL JOURNAL

do) $\bigcirc$ 요

\section{A CONCEPTUAL STUDY ON THE EFFECT OF NARIKELA KHANDA IN AMLAPITTA}

\section{$\underline{\text { Balaji Thakur }}^{1}$ Priyanka Kumari $^{2}$, $\underline{\text { Bhanu Pratap Singh }}^{3}$}

${ }^{1}$ P.G. Scholar, P. G. Dept. of Kriya Sharir, National Institute of Ayurveda, Jaipur, Rajasthan, India

${ }^{2}$ P.G. Scholar, P. G. Dept. of Kriya Sharir, National Institute of Ayurveda, Jaipur, Rajasthan, India

${ }^{3}$ Assistant Professor, P. G. Dept. of Kriya Sharir, National Institute of Ayurveda, Jaipur, Rajasthan, India

Corresponding Author: balajithakur92@gmail.com

\section{https://doi.org/10.46607/iamj2209092021}

(Published Online: September 2021)

Open Access

(C) International Ayurvedic Medical Journal, India 2021

Article Received: 05/08//2021 - Peer Reviewed: 23/08/2021 - Accepted for Publication: 24/08/2021

\section{Check for updates}

\begin{abstract}
Nowadays due to unawareness about Prakriti (psychosomatic constitution) people are practising inappropriate diet and lifestyle which leads to disturbances in the digestive system. The core principles in Ayurveda give prime importance to Agni, Prakriti, Ahara (food) and Vihara (lifestyle) in maintaining health. In the present era, people are scheduled to one or the other works due to which they are following unwholesome food and habits which may lead to the manifestation of many diseases. One of the common disorders which troubles a person a lot is Amlapitta. It is composed of the word Amla and Pitta. Amlapitta is a very common disease caused by Vidagdha Pitta with features like Amlaudgara, Tiktaudgara, Hrud Kantha Daha etc. It is the GI disorder described in Ayurvedic texts that closely resembles Gastritis in modern science. In the chronic stage, it may lead to ulcerative colitis. In modern medical science, they give some anta-acids, H2 blockers, Proton pump inhibitors, some steroids which have high prevalence costs and side effects. Today there is a need for a potent herbal formulation that can cure hyperacidity and ulcers. The present study is being undertaken to approach the disease Amlapitta through the formulation of Narikela Khanda.
\end{abstract}

Keywords: Ayurveda, Amlapitta, Narikela Khanda. 


\section{INTRODUCTION}

In a sedentary lifestyle, many diseases come across. Amlapitta is a very common disease in society due to improper habits of food intake and due to a hectic lifestyle.

Amlapitta is a disease caused due to vitiation of certain attributes of Pitta like the Drava Guna and Amla Guna causing Vidagdhajirna at the initial stage and later it causes inflammation and corrosion of the Sleshmadhara Kala of the Amashaya i.e. mucous membrane of the stomach and duodenum. In modern science, Vidagdhajirna can correlate to simple dyspepsia and Amlapitta as hyperacidity/Gastritis. ${ }^{1}$

Charaka Samhita indicates that the Grahani Dosha and Amlapitta occur in the persons who do not check the temptation of food. It has a predominance of vitiated Pachaka Pitta and involves vitiation of Annavaha and Purishavaha Srotas. ${ }^{2}$

The pathology includes Mandagni \& the formation of Ama. Excessive consumption of Amla, Katu, Tikshna Ahara is faulty dietary habits, addictions like alcohol, smoking, tobacco chewing and other psychological factors like stress, the strain also contributes to causing the Amlapitta disease. The clinical features of Amlapitta, mentioned in our classics are Avipaka, Klama, Utklesha, Tikta Amlaudgara, Gaurava, Hrud Kantha Daha, Aruchi and Chardi. ${ }^{3}$

The treatment principles namely Nidana Parivarjana and Samprapti Vighatana are also applicable in the treatment of Amlapitta. The use of Shamana Aushadhi can provide great relief to the patients.

Acharya has been told to use the drugs which are having Tikta-Madhura Rasa, Madhura Vipaka, Sheeta Virya and Laghu, Ruksha Guna with Kapha-Pittahara property.
Gastric disorders like hyperacidity and ulcers are common clinical entities. These are major health problems with multifunctional aetiology. The development of gastric ulcers occurs with acid and the breakdown of mucosal defence. Local mechanisms implicated in mucosal defence are mucous-like alkaline secretions, mucosal hydrophilic activity, rapid epithelial cell renewal, rich mucosal blood flow and increased resistance of gland cells in deep mucosa to acid and peptic activity. Rational therapy for gastric ulcers remains elusive and a search for safer potential drugs is being carried out. The use of natural drugs in gastric ulcers is well documented. Most of these drugs augment the mucosal defensive factors, which are thought to be important for the protection of gastric mucosa. ${ }^{4}$

\section{SAMPRAPTI OF AMLAPITTA}

Amlapitta is a disease of Pitta dominancy. Pitta normally has dominancy of Agni with Jala Mahabhuta. If the proportions of these two Mahabhuta in Pitta get changed then Pitta becomes vitiated leading to various disease manifestations like Amlapitta. This vitiation of Pitta can be categorized into two groups Drava Guna dominated Pitta Vriddhi (Jala Mahabhuta portion of Pitta increases) \& Ushna Guna dominated Pitta Vriddhi (Agni Mahabhuta portion of Pitta increases).

Few Nidana may increase Pitta Drava Guna (by increasing the Jalamahabhuta proportion) while other Nidana may increase Pitta Ushna-Tikshna Guna (by increasing the Agni mahabhuta proportion).

Few Nidana can increase the Pitta Drava Guna or Ushna-Tikshna Guna or both e.g. Viruddha Ahara having Amla-Lavana-Snigdha-Ushna Drava Guna then Pitta vitiate with Drava Guna \& Viruddha Ahara having Katu-Ruksha-Ushna Guna then Pitta vitiate with Ushna-Tikshna Guna.

\section{Nidana Sevana \\ 1 \\ Ushna Tikshna Ahara Desha Visesh-Anupadesh Ritu Visesh-Varsha, Sharad

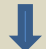 \\ PittaPrakopa Drava, Ushna-Tikhna Guna Vrudhi Pittaja Vidagdha Bhav \\ Vidagdha Anna in Pachyamana remains undigested undergoes \\ Shuktatwa leading to Amlapitta}




\section{SAMPRAPTI GHATAK}

Dosha - Pachaka Pitta

Dushya - Rasa and Rakta Dhatu Adhistana Amashaya, Grahani

Srotas - Annavaha Srotas, Rasavaha Srotas, Purishvaha Srotas Srotadusti - Vimarga Gamana, Atipravruti

Agni - Mandagni

Marga - Abhyantara, Koshtha Svarupa - Chirakari

Prabhava - Daruna

\section{NARIKELA KHANDA}

Narikela Khanda is an Ayurvedic preparation which is a modified state of Avaleha preparation, which is prepared by using pulp (endosperm) of coconut, coconut water and other ingredients.

Narikela (Cocus Nucifera Linn.) is a commonly available fruit that is consumed almost daily in Indian food and its use in medicine is also not uncommon. Many preparations out of it are described in classical texts of Ayurveda. Narikela Khanda is a formulation that is prepared by using Narikela as a chief ingredient. Khanda is a popular dosage form in Ayurveda. Narikela Khanda granules is a modified method of Narikela Khanda which is prepared in the form of granules by keeping the ingredients the same to enhance stability. Narikela Khanda was popularly used to treat Amlapitta (hyperacidity). ${ }^{5}$

\section{METHOD OF PREPARATION:}

Fresh coconut ware broke, and water and pulp are collected in separate vessels. The pulp is transformed into paste form and then fried with ghee till ghee starts to separate from the paste. The coconut water is filtered with a sieve and Khanda Sharkara (sugar candy) is added to it and then kept on Mandagni for preparing Paka. When Paka Siddhi Lakshana is seen, the fried pulp is added and then the Prakshepaka Dravya like Dhanyaka, Pippali, Musta, Vamsalochana, Shweta Jiraka, Krishna Jiraka, Twak, Ela, Tejapatra, Nagakeshara are added and mixed thoroughly and stored in airtight pet bottles

\section{INGREDIENTS}

1. Narikela - Cocus Nucifera - pulp -192g

2. Goghrita - clarified butter- $48 \mathrm{~g}$

3. KhandaSharkara - candy sugar - 192g

4. Narikelajala - Cocus nucifera - water- $768 \mathrm{~g}$

5. Dhanyaka - Coriandrum sativam - Fruit - $3 g$

6. Pippali - Piper longum Fruit - 3g

7. Musta-Cyperus rotundus - Rhizome- $3 \mathrm{~g}$

8. Vamsalochana - Bambusa arundinaceae - Silicaeous concretion - $3 \mathrm{~g}$

9. Sweta jiraka - Cuminum cyminum - Fruit - 3g

10. Krishna jiraka - Carum carvi - Fruit - 3g

11. Twak-Cinnamomum zeylanicum - Stem bark - 3g

12. Tejapatra-Cinnamomum tamala - leaf $-3 \mathrm{~g}$

13. Nagakeshara-Mesua ferrea - Stamen -3g

\section{DISCUSSION}

\begin{tabular}{|c|c|c|c|c|c|}
\hline DRUGS & $R A S A$ & GUNA & VIRYA & VIPAKA & KARMA \\
\hline NARIKELA & Madhura & Guru Snighda & Sita & Madhura & Vatapita Hara \\
\hline DHANYAKA & $\begin{array}{l}\text { Kasaya, Tikta, Madhura, } \\
\text { Katu }\end{array}$ & $\begin{array}{l}\text { Laghu, } \\
\text { Snigdha }\end{array}$ & Ushna & Madhura & Tridoshah ara \\
\hline PIPPALI & Madhura & Guru, Snigdha & $\begin{array}{l}\text { Anushna- } \\
\text { shita }\end{array}$ & Madhura & $\begin{array}{l}\text { Yogavahi } \\
\text { Pitashamaka }\end{array}$ \\
\hline MUSTA & $\begin{array}{l}\text { Tikta, } \\
\text { Kashaya }\end{array}$ & $\begin{array}{l}\text { Laghu, } \\
\text { Ruksha }\end{array}$ & Sita & Katu & $\begin{array}{l}\text { Kapha } \\
\text { Pitta Hara }\end{array}$ \\
\hline SWETA JIRAKA & Katu & $\begin{array}{l}\text { Laghu, } \\
\text { Ruksha }\end{array}$ & Ushna & Katu & $\begin{array}{l}\text { Kapha- } \\
\text { Vata Hara }\end{array}$ \\
\hline $\begin{array}{l}\text { KRISHNA } \\
\text { JIRAKA }\end{array}$ & Katu & $\begin{array}{l}\text { Laghu, } \\
\text { Ruksha }\end{array}$ & Ushna & Katu & $\begin{array}{l}\text { Kapha- } \\
\text { vata Hara }\end{array}$ \\
\hline VANSALOCHANA & $\begin{array}{l}\text { Madhura, } \\
\text { Kashaya }\end{array}$ & $\begin{array}{l}\text { Ruksha, Katu, } \\
\text { Tikshna }\end{array}$ & Shita & Madhura & $\begin{array}{l}\text { Vata-Pitta } \\
\text { Hara }\end{array}$ \\
\hline
\end{tabular}




\begin{tabular}{|l|l|l|l|l|l|}
\hline TWAK & Katu, Tikta, Madhura & $\begin{array}{l}\text { Laghu, } \\
\text { Ruksha, } \\
\text { Tikshna }\end{array}$ & Ushna & Katu & $\begin{array}{l}\text { Vata- kapha } \\
\text { Hara }\end{array}$ \\
\hline TEJAPATRA & $\begin{array}{l}\text { Katu, } \\
\text { Madhura }\end{array}$ & $\begin{array}{l}\text { Laghu, } \\
\text { Ruksha, } \\
\text { Tikshna }\end{array}$ & Ushna & Katu & $\begin{array}{l}\text { Vata- } \\
\text { kapha Hara }\end{array}$ \\
\hline NAGAKESHARA & $\begin{array}{l}\text { Madhura, } \\
\text { Kashaya } \\
\text { Ruksha, Shita }\end{array}$ & Shita & Madhura & $\begin{array}{l}\text { Kapha } \\
\text { Pitta Hara }\end{array}$ \\
\hline
\end{tabular}

The properties of contents of Narikela Khanda-

\section{NARIKELA-}

Modern - Coconuts are high in fibre which helps bulk up your stool and supports bowel regularity. It is rich in manganese which supports enzyme function and fat metabolism. Coconuts are also found to strengthen your Gut bacteria. ${ }^{6}$

Ayurvedic - It is Madhura Rasa, Madhura Vipaka having Shita Veerya with Snigdha Guna that helps to eliminate Vata Pitta Dosha. ${ }^{7}$

\section{DHANYAKA}

Modern - In Dhanyaka, Linalool and Borneol help enhance digestion, liver function as well as bowel movements that further helps in reduce Diarrhoea. ${ }^{8}$

Ayurvedic- Its Rasa is Madhura, Tikta, Kashaya with Laghu Guna that helps in Pitta Shamana. ${ }^{9}$

\section{PIPPALI}

Modern - Piperine, an alkaloid of long peepers, inhibited gastric emptying (GE).GE inhibitory activity of piperine is independent of gastric acid and pepsin secretion. ${ }^{10}$ Ayurvedic - Pippali has Madhura Rasa with Madhura Vipaka having Anushnasita Veerya for that it helps in Pitta Shamana. ${ }^{11}$

\section{MUSTA}

Modern - Essential oil of Musta has an anti-inflammatory effect and a high level of antioxidants.

Ayurvedic - Musta has Laghu and Shita Veerya which helps in Pitta Shamana. ${ }^{12}$

\section{JIRAKA}

Modern - A particular compound called Thymol found in cumin seeds stimulates Gastric Gland secretion. This helps to breakdown complex nutrients like proteins, fat and sugar to keep your gut healthy and keeps digestive issues such as indigestion, nausea etc. 13
Ayurvedic - It is Ushna Veerya and Laghu in nature that helps to eliminate Ama Dosha. ${ }^{14}$

\section{VANSHALOCHANA}

Modern - Silica components of Vansalochana help in local protection to the mucus membrane of the G.I. tract.

Ayurvedic - It is Madhura Kashaya Rasa, Madhura Vipaka and Shita Veerya that helps in Pitta Shamana. ${ }^{15}$

\section{TWAK and TEJAPATRA}

Modern - Cinnamon help decrease stomach acid and pepsin secretion from the stomach walls after eating which reduces $\mathrm{CO} 2$ gas, raises $\mathrm{pH}$, lowers metabolic heat and cool your stomach down. ${ }^{16}$

Ayurvedic - Twak and Tejapatra is Madhura, Tikta Rasa having Laghu in nature that helps in Pitta Shamana. $^{17}$

\section{NAGAKESARA}

Modern - Xanthones component of Messua Ferra showed anti-ulcer activity. Essential oil of M. Ferra contains anti-inflammatory and pain soothing effects. Ayurvedic - Nagakesara has Madhura, Kashaya Rasa, Madhura Vipaka having

Shita Veerya helps in Pitta Shamana. ${ }^{18}$

In Narikela Khanda, most of the ingredients of having Kasaya, Tikta and Madhura predominant Rasa, Laghu, Ruksha, Tikshna Guna, Ushna and Shita Virya which improves the status of Agni subsequently prevent the Ama formation and vitiation of Dosha. Tiktata, Amlata in Udgara and Daha in Hrudkantha are due to Vidagdha Pitta, which is relieved by Pittashamaka Rasa and Vipaka present in ingredients of the formulation. Symptoms of Amlapitta are almost similar to symptoms of Ama. Here Pippali and Dhanyaka both act as Dipana, Pachaka and Rochana and Dosha Samshodhan. By treating Ama, the symptoms like Aruchi, Gaurava, Avipaka, Utklesha and Klama 
are relieved. Due to increased Ushna Guna of Pitta symptoms like Hruddaha and Kanthadaha appears. Narikela is having Madhura Rasa, Madhura Vipaka, Shita Veerya, Pitta Vatahara. By its Agni Dipaka property and Pitta shamaka nature it does the Samprapti Vighatana on Amlapitta.

\section{CONCLUSION}

From the above perspective, it can be concluded that Narikela Khanda has anti acidic and anti-ulcer activity. As most of the drugs having Madhura, Tikta, Kashaya Rasa, Madhura Vipaka and Shita Veerya that helps in Shamana of aggravated Pitta Dosha. Narikela Khand is Madhura in taste so people of all age groups can easily consume this medicine. It is cost-effective and can be easily prepared at home, so it is very helpful in the GI tract disorders like Amlapitta, Grahani.

\section{REFERENCES}

1. Prof. Yadunandana Upadhyaya Editor, commentary Madhukosh of Vd. Shri Sudarshanshatri On Madhav Nidan (Part 2) Of Madhavkar; Amlapitta Nidanam: Chapter 51, Verse 8. Varanasi: Chaukhamba Prakashan, 2008 Ed.

2. Agnivesha, Charaka, Dridhabala, CharakaSamhita, Vaidya Jadavaji Trikamji Aacharya Editor Sutrasthana, Annapanavidhi Adhyaya, 27/342, Reprint Ed. Varanasi: Chaukhambha Surabharati Prakashana; 2005

3. Yadunandana Upadhyaya Editor, commentary Madhukosh of Vd. Shri Sudarshan shatri On Madhav Nidan (Part 2) Of Madhavkar; Amlapitta Nidanam: Chapter 51, Verse 8. Varanasi: Chaukhamba Prakashan, 2008 edition; P. 202.

4. Konturek S.J., 1985, Gastric Cytoprotection And gastroenterology, Vol-20, Pg.-543

5. Shastri A, Bhaishajya Ratnavali. 18th Ed. Varanasi, Chaukhambha Sanskrit Sansthana; 2005:464

6. www.Scienecebeta.Com, Coconut for Acid Reflux Relief, 2020-04-29

7. Dravya Guna Vigyan, Priyabrata Sharma, Vol-2, Chaukhamba Bharati Academy Edition 2005- Page No.117

8. www.Planetayurveda.Com By Dr Meenakshi Chauhan Published on May 8, 2019

9. Dravya Guna Vigyan, Priyabrata Sharma, Vol-2, Chaukhamba Bharati Academy Edition 2005 Page No.322

10. www.Ayurgamaya.Com By Salilla Sukumaran,2020

11. Dravya Guna Vigyan, Priyabrata Sharma, Vol-2,
Chaukhamba Bharati Academy Edition 2005 Page No. 275

12. Dravya Guna Vigyan, Priyabrata Sharma, Vol-2, Chaukhamba Bharati Academy Edition 2005 Page No.370

13. www.Webmd.Com-Cumin

14. Dravya Guna Vigyan, Priyabrata Sharma, Vol-2, Chaukhamba Bharati Academy Edition 2005 Page No.365

15. Www.Ayurtimes.Com By Dr Jagadev Singh Published On Sept. 10, 2015

16. www.Healthy.Net-Cinnamon ByBetty Ellis

17. Dravya Guna Vigyan, Priyabrata Sharma, Vol-2, Chaukhamba Bharati Academy Edition 2005 Page No.250

18. Dravya Guna Vigyan, Priyabrata Sharma, Vol-2, Chaukhamba Bharati Academy Edition 2005 Page No.783

\section{Source of Support: Nil Conflict of Interest: None Declared}

How to cite this URL: Balaji Thakur et al: A Conceptual Study On The Effect Of Narikela Khanda In Amlapitta. International Ayurvedic Medical Journal \{online\} 2021 \{cited September 2021\} Available from: http://www.iamj.in/posts/images/upload/2073_2077.pdf 